\title{
UK Teachers' and Learners' Experiences of CLIL Resulting from the EU-funded Project ECLILT ${ }^{1}$
}

\section{Las experiencias de profesores y aprendices del Reino Unido en AICLE como resultado del proyecto ECLILT financiado por la}

\author{
Marilyn HunT \\ University of Warwick \\ (Warwick, UK)
}

\begin{abstract}
This paper reports on the EU-funded project ECLILT (e-based Content and Language Integrated Learning Training), which developed a blended, trans-national model training course adaptable to different countries for CLIL (Content and Language Integrated Learning) teacher trainers and pre-service and in-service school subject teachers in CLIL in order to tackle the absence of qualified trainers and the shortage of appropriately skilled teachers in CLIL. The paper outlines how the partners developed the training course and how it was implemented specifically in the UK. A classroom-based action research approach was adopted for this UK study, as it sought to bring about practical improvements and innovations and implement change in one aspect of teacher education. Data were collected through questionnaires to teachers to evaluate the impact on teaching and learning through this approach. Initial findings indicate a positive impact on pupil learning and on teachers' practice across the curriculum.
\end{abstract}

Key Words: CLIL; teacher education; teacher training.

\section{Resumen}

Este documento presenta un reporte sobre el proyecto ECLILT (e-based Content and Language Integrated Learning Training) financiado por la Unión Europea, la que desarrolló un curso modelo transnacional de formación docente en la modalidad híbrida, adaptable a diferentes países, para formadores de docentes de AICLE (Aprendizaje Integrado de Contenidos y Lenguas Extranjeras) y docentes de escuela en formación inicial y en ejercicio, con el fin de hacer frente a la falta de instructores calificados y la escasez de maestros debidamente capacitados en AICLE. En este artículo se describe cómo se desarrolló el curso de capacitación y la forma en que se llevó a cabo especificamente en el Reino Unido. Se adoptó un enfoque de investigaciónacción basado en el aula para este estudio, ya que se trató de producir innovaciones y mejoras prácticas, así como de implementar el cambio en un aspecto de la formación del profesorado. Los datos fueron recolectados a través de cuestionarios a los profesores para evaluar el impacto en la enseñanza y el aprendizaje a través de este enfoque. Los resultados iniciales indican un impacto positivo en el aprendizaje del alumno y en la práctica docente a través del currículo.

Palabras Claves: AICLE; formación docente; capacitación docente.

${ }^{1}$ ECLILT (e-based Content and Language Integrated Learning Training)

LACLIIL Hunt, M. (2011). UK teachers' and learners' experiences of CLIL resulting from the EU-funded project ECLILT. Latin American Joumal of Content \& Language Integrated Leaming, 4(1), 27-39. doi: 10.5294/lacli1.2011.4.1.3 ISSN 2011-6721. 


\section{INTRODUCTION}

This paper reports on an EU funded project ECLILT (e-based Content and Language Integrated Learning Training), with partners in Italy, Slovakia, Poland, Spain, Austria, France, Greece, UK and Turkey which sought to develop a blended, trans-national model training course adaptable to different countries for pre-service and in-service school subject teachers in CLIL (Content and Language Integrated Learning) in order to tackle the absence of qualified trainers and the shortage of appropriately skilled teachers in CLIL. The paper starts with a definition of CLIL and goes on to investigate international research and developments in CLIL and the situation in the UK. It reports on the aims of the ECLILT project, how the partners developed the training course, and how the training was implemented specifically in the UK. The research study sought to determine the impact of the ECLILT training on the teacher participants and their learners through an action research approach. Initial findings are reported and the paper concludes with a discussion of the outcomes.

\section{DEFINITION OF CLIL}

CLIL is a relatively new approach to learning where content is learnt through the foreign language in an integrated way so that language learning is linked with other areas of the curriculum. Marsh (2002, p. 15) describes CLIL as "any dual-focused educational context in which an additional language, thus not usually the first language of the learners involved, is used as a medium in the teaching and learning of non-language content". The advantages of this approach are that the teaching is focused on content whilst language is used for an authentic purpose and is assimilated in a natural context. This can boost learners' motivation to learn languages.

\section{International research on CLIL developments}

A plethora of models of bilingual education or immersion programs where content is learnt through the foreign language have existed with a range of priorities, aims and outcomes. Coyle (2007, p. 543) describes it as "a complex business involving wide-ranging variables in very diverse contexts, rooted in historical and sociopolitical developments". One of the first to be subjected to intensive long-term research evaluation were the French immersion programs developed in Canada since the 1960s, designed primarily "to provide Canada's majority-group English-speaking learners with opportunities to learn Canada's other official language" (Genesee, 1994, p. 1). These programs, based on the teaching of non-linguistic subjects in French to children whose native language was English, produced positive results according to the research. Cummins (1999) summed up research over 30 years which found that students gain fluency and literacy in French at no apparent cost to their English academic skills; that there is no evidence of any long-term lag in mastery of subject matter taught through French and with respect to French skills, by the end of elementary school (grade 6), students are close to the level of native speakers in understanding and reading French, although their expressive skills of spoken and written French are less well-developed. While the Canadian experience is not necessarily directly transferable to Europe, it has nevertheless stimulated valuable research in this area and encouraged a wide range of experimental activity.

In Europe, interest in bilingual education methodologies started to increase in the 1990s due to European socio-economic integration and globalization. This was further developed

LACLII Hunt, M. (2011). UK teachers' and learners' experiences of CLIL resulting from the EU-funded project ECLILT. Latin American Joumal of Content \& Language Integrated Leaming, 4(1), 27-39. doi: 10.5294/lacli1.2011.4.1.3 ISSN 2011-6721. 
through Council of Europe activities and in 1996 the term CLIL was introduced (CLIL compendium online). One of the aims of the European Commission stipulated in the Action Plan 2004-2006 (Commission of the European Communities, 2003, p. 7) advocated "mother tongue plus two other languages". The Action Plan also emphasized that CLIL should significantly contribute to achieving the goals of language education and provide opportunities for pupils to use their language skills alongside immediacy of purpose:

It opens doors on languages for a broader range of learners, nurturing self-confidence in young learners and those who have not responded well to formal language instruction in general education. It provides exposure to the language without requiring extra time in the curriculum, which can be of particular interest in vocational settings. (Action Plan 2004-6, p. 8)

CLIL is supported by the European Commission and European Council and is also one of the priorities of national governments. Several major European organizations specializing in CLIL projects have emerged and there have been numerous initiatives throughout the European Union to promote this approach. A Eurydice publication (2006) offers an interesting analysis of CLIL provision in the education system. It deals with the status of languages and levels of education concerned, examines the aims and range of subjects taught through a foreign language, considers evaluation and certification and discusses factors inhibiting the general implementation of CLIL.

CLIL has gained support from political authorities because it contributes to the development of multilingual interests and attitudes, prepares learners for internationalization and provides learners access to the wider cultural context. It is believed that languages will play a key role in curricula across Europe and the combination of subjects and languages offers learners a better preparation for life in Europe, in which mobility is becoming increasingly more widespread. CLIL is considered as a way to promote an improvement in language competence and especially in communication skills to be used in real-life situations.

Marsh and Langé (2002, p. 8) claim that CLIL promotes not only linguistic competence but also cognitive development and thinking skills:

Because of the different "thinking horizons" which result from working in another language, CLIL can also have an impact on conceptualisation, literally how we think. Being able to think about something in different languages can enrich our understanding of concepts, and help broaden our conceptual mapping resources. This allows better association of different concepts and helps the learner go towards a more sophisticated level of learning in general.

The international research outlined in this section includes well-documented intensive long-term research of immersion programs in Canada and the development of CLIL in Europe. In all cases the benefits of CLIL appear to be an improvement to language skills with no detrimental impact on the content subject. Indeed, CLIL can lead to the enhancement of cognitive development and thinking skills.

\section{CLIL in the UK}

The situation in the UK, as an English speaking country, is somewhat different from other European countries. The Nuffield Languages Inquiry (2000) recommended that there should be a nationally coordinated program of bilingual learning in the UK (that is, studying a curriculum subject through the medium of a foreign language). Following this, the use of the CLIL approach started in the UK with the Content and Language Integration Project (CLIP) hosted by CILT (Centre for Information on Language Teaching, now the National Centre for Languages). This 
three year pilot study ran in eight project schools at both primary and secondary level from $2002 .^{2}$

The Languages Review (DfES, 2007, p. 15) reinforced the potential for using the CLIL approach recommending "the introduction of more stimulating and relevant content" to the languages syllabus; "clear guidelines and support for a more appropriate and varied content to the secondary languages curriculum" and "opportunities to think through how language learning can be integrated into parts of other learning (CLIL) ... so that the language can be used in motivating contexts without detriment to learning in the target discipline" (DfES, 2007, p. 16). Whilst some schools continued to develop initiatives, this approach nevertheless still remains relatively innovative in England. The focus on CLIL was further strengthened by the publication of CLIL National Statement and Guidelines (2009).

There remain some concerns currently about foreign language learning in England. Following the decision in England (DfES, 2002) to remove the requirement for all pupils to learn a foreign language at key stage 4 (KS4, ages 14-16), there have been dramatic decreases in the number of KS4 pupils taking a language GCSE. In 2001, 78\% of KS4 pupils took a language at GCSE, 50\% in 2006 and 44\% in 2008 and 2009 (CILT, 2009). Thus, once the compulsory nature of language learning was removed, students increasingly opted not to study a language and to instead study subjects that appeared more appealing to them.

\section{METHODOLOGY}

\section{Aims of the ECLILT project}

The ECLILT project (2007-9) was set up as a consortium of eight partner countries with the aim of enhancing the quality and European dimension of teacher training in CLIL through the organization and delivery of pilot courses to stimulate the introduction of CLIL provision on a broader scale in secondary schools (pupils aged 11-18). The aims of the project can be divided into a teaching and learning dimension (to widen the European network of institutions involved in CLIL, promoting the use of interactive methodologies and in training for an innovative combination of subject and language teaching) and a cultural dimension (to support multilingualism in Europe, promoting linguistic diversity, intercultural dialogue, understanding of human cultural differences and preparing citizens in Europe to the advantages of a more widespread mobility and encourage understanding, tolerance and respect).

The goals of the project were to:

1. Create a blended, trans-national model training course (on-line and face-to-face) for CLIL teacher trainers and pre-service and in-service secondary school subject teachers in CLIL adaptable to different countries, consisting of 120 hours (30 contact hours and an on-line component of 90 hours)

2. Provide a course guide book with sample material in the eight target languages

3. Create a CD-ROM with simulations of the way the learning platform's functionality and content have been exploited, together with extensive samples of the course material and peer exchanges.

\footnotetext{
${ }^{2}$ For more information, see the CILT Web site at: http://www.cilt.org.uk/.
} 


\section{ECLILT project development and outcomes}

Initial audits of CLIL in each country revealed great diversity. In some countries, for example France, Poland and Slovakia, bilingual streams have existed for some years; in some countries such as Italy, Spain and England, CLIL has been developing through pilot initiatives, and in Turkey and Greece CLIL is completely new.

The partners involved in the consortium had considerable expertise in teacher training or teaching and brought into the project their different experiences and approaches to CLIL, to exchange practices and contribute to support countries like Greece and Turkey where there was a total absence of teacher training in CLIL. A trans-national, model training course for CLIL teacher trainers was created through collaborative work between the partners adaptable to different countries, languages and subjects. The training course was designed for CLIL teacher trainers working with pre-service and in-service secondary school subject teachers (teaching or planning to teach at various schools, where CLIL is, or could be, part of the curriculum). The aim was that these teachers could increase their competences by means of positive teamwork with language teachers. Initially, the partners agreed on the content of the on-line course and materials were produced to cover three main areas with relative subsections:

1. Introduction to CLIL (What is CLIL? Why CLIL? Who?).

2. Planning and assessment.

3. Adapting methodology for CLIL (Learning \& teaching language skills, Learner Autonomy, Co-operative learning, Grouping students, Vocabulary and vocabulary information sources, The use of Technologies, Classroom language, Task-based approach \& project work).

An approach employing an innovative use of ICT (Information and Communication Technologies) was developed to create a web platform for learning and these materials were adapted for the platform and e-learning. ICT was therefore fundamental both for providing information, the pedagogic content of the training and later teaching resources. In addition, the ECLILT partners wanted to encourage good practice in CLIL teaching through the development of new competences and expertise in teaching, the stimulation of discussion on skills-oriented and task-based approaches, project work, co-operative learning, cross-curricular work, and team teaching and the use of various learning strategies in a situation where both the teacher and the learners may not master the working language at a high level. The consortium strongly believed that the CLIL approach is more successful if the activities conducted are learner-oriented applying principles of co-operative learning and this methodology was applied both in face-toface training sessions and in the self-contained collaborative learning platform.

The face-to-face course was then developed as a pilot course in Greece in November 2008 to be followed by national courses in each of the partner countries. The established experience in teacher training in several partner institutions provided the basis for the pedagogic approach which was applied in the draft model training program and all partners participated in the design and delivery of the training. Greece was chosen for the location of the pilot training, as this was a country where there was no experience of CLIL and therefore the pilot course could be used to initiate the development of CLIL in schools in Greece. To cover the wide range of methodological areas that need to be taken into consideration when training CLIL teachers, the partnership applied and modeled the main pedagogical methodologies in the course itself. All the units were designed to involve trainees in the training method and encourage them to develop CLIL activities, try them out, and evaluate them. This kind of experiential learning gave

LACLil Hunt, M. (2011). UK teachers' and learners' experiences of CLIL resulting from the EU-funded project ECLILT. Latin American Joumal of Content \& Language Integrated Leaming, 4(1), 27-39. doi: 10.5294/lacli1.2011.4.1.3 ISSN 2011-6721. 
participants the opportunity to experience methodologies and different kinds of activities they themselves could use in the classroom with their own learners.

The pilot and the transnational training courses were seen as testing sessions for the methodology, the content and the entire course structure used. As a result of the feedback from the pilot course, national courses were developed in each of the partner countries tailored to their own needs. The course aimed to introduce and/or spread CLIL in the participant countries, addressing the constraints posed by the lack of skilled teacher trainers for CLIL and the absence of pilot courses and CLIL provision in some countries.

\section{ECLILT course in the UK}

The ECLILT training course was adapted for the UK setting and took place at the University of Warwick in a series of five twilight sessions from January to July 2009. The initial objective of the UK national training was to take the training one stage further than the pilot course in Greece so that participants would teach the lessons and resources they planned as a result of the training sessions and report back in the final session how they had worked in school.

\section{Research methodology}

The focus of the research was to determine:

- What changes do teachers make in planning, resources and methodology to support the CLIL approach?

- How does the CLIL approach affect pupil behavior, attitude and motivation?

- What is the impact of the CLIL training on teachers' teaching and their views of teaching?

A classroom-based action research approach was adopted for this project. Picciano (2004) defines action research projects as school-based studies that seek to improve performance and solve problems. Indeed, the aim of an action research project is to bring about practical improvements and innovations, implement a change or develop social practice. Zuber-Skerritt (1996) makes it clear that action research can bring about practical improvement, innovation, change and practitioners' better understanding of their practices. Burns (2005, p. 58) defines action research as a response to a perceived problem or an identified "gap" related to, for example, teaching, learning and the curriculum. In this case there was a desire to improve an aspect of teacher education by including innovative practice in CLIL and disseminating this to a broad range of schools.

\section{Data collection, sources and analysis}

Data were collected by means of a questionnaire to investigate how teachers changed their practice in order to teach subject content through language. The questionnaire was administered at the end of the course. As the number of respondents was relatively small the questionnaire contained mainly open questions in order to gain qualitative responses of an interpretive nature. It sought to identify to what extent the training supported the teachers' preparation for CLIL teaching in school using a scale of 6 (fully) to 1 (not at all). Five open questions sought to investigate how the teachers adapted their resources, planning and methodology to support CLIL; and to discover which elements of the lesson were conducted in the target language (French, Spanish or German) and which in the mother tongue (English):

LACLII Hunt, M. (2011). UK teachers' and learners' experiences of CLIL resulting from the EU-funded project ECLILT. Latin American Joumal of Content \& Language Integrated Leaming, 4(1), 27-39. doi: 10.5294/lacli1.2011.4.1.3 ISSN 2011-6721. 
- How did you adapt your resources to support the CLIL approach?

- How did you adapt your planning to support the CLIL approach?

- How did you adapt your methodology to support the CLIL approach?

- Which elements of the lesson were conducted in the target language? Why?

- Which elements of the lesson were conducted in English? Why?

The following five questions were related to pupil learning and response to this approach: their understanding of the subject content; strategies used by the teacher to aid pupil understanding; perceived differences in pupil behavior, attitude, motivation in CLIL lessons, differences in pupil learning; and gains in pupil learning:

- To what extent did the pupils understand the subject content?

- What strategies did you use to help pupils understand and communicate?

- Did you notice any difference in pupil behavior/attitude/motivation in the CLIL lesson? Please explain.

- Did you notice any difference in pupil learning in the CLIL lesson? Please explain.

- Give brief examples of gains in pupils' learning.

The final two questions investigated teacher confidence in delivering CLIL lessons in future and the impact of the CLIL training on their teaching and views of teaching:

- How confident do you now feel about delivering CLIL lessons in the future? Please explain.

- What impact do you think your CLIL training has had on your teaching and views of teaching?

A total of 25 participants attended the ECLILT national course including teachers of Science, Maths, Music, Geography, History, PSHE (Personal, Social and Health Education) as well as teachers of French, Spanish and German. Teachers were recruited from the Warwick Institute of Education Partnership Schools. Letters were sent initially to languages departments inviting them to bring subject colleagues to the training. Seventeen participants responded to the questionnaire. Whilst this is a small-scale sample, some very valuable elements of the impact of CLIL on learning and practice are revealed.

Data were grouped and explored thematically using a coding frame to categorize the themes emerging from the responses to give depth and meaning to the points made.

\section{RESULTS}

The questionnaire findings showed that the participants were very positive about the face-to-face ECLILT training. On a scale of 6 (fully) to 1 (not at all), four teachers rated the extent to which they felt the training supported their preparation for CLIL teaching in school as 6 , nine 5, three 4 and one 3 . Thus 13 out of 17 felt fully or very supported. Participants were less positive about the on-line materials, mainly because they reported that they did not have very much time to access them.

The teachers planned CLIL lessons and taught them in school. Subjects covered were Science (in French and Spanish), Maths (in French), Music (in French), Geography (in Spanish), Citizenship (in French), History (in Spanish and German) and PSHE (in French). In response to how teachers adapted their resources to support the CLIL approach, most teachers carefully considered the language input to make it accessible. For example, teachers streamlined and simplified everything removing any ambiguity (5), used visuals (8) and cognates (5), used simple, clear target language (5), thought very carefully about the vocabulary to be used and how

LACLil Hunt, M. (2011). UK teachers' and learners' experiences of CLIL resulting from the EU-funded project ECLILT. Latin American Joumal of Content \& Language Integrated Leaming, 4(1), 27-39. doi: 10.5294/lacli1.2011.4.1.3 ISSN 2011-6721. 
to present it (2), incorporated linguistic structures the teacher knew were embedded to ensure pupils could access the lesson (4), gave short focused instructions, straightforward examples and scaffolded the language to enable discussion and opinions (5). In two cases the same type of resources as usual for the subject were used but translated in the target language. One teacher retained some materials in English, as they were too difficult. Some teachers changed their activities to include interactive material (3), a kinesthetic approach (2), a variety of tasks (2), and reduction in the amount of writing. The change in emphasis to use visuals and clear, specific language affected practice in the host subject as this typical quote demonstrates:

- "As a non-experienced CLIL teacher it seems an excellent idea. The resources we have developed for CLIL could be very useful also in a normal Music lesson. The resources CLIL require are so multi-intelligent for all pupils and help to develop thinking skills."

Teachers were asked how they adapted their planning to support the CLIL approach. It was clear that collaboration (6) was an important element including meeting with the other subject teacher to exchange and clarify ideas and ensure the teaching benefitted that and not just MFL (2). Some approached it from the subject content (5) with a clear stepped approach (2), a lot of forward planning, reflection and evaluation (2). Some commented on the need to target the content closely to the learning outcomes (5), ensuring that the content was not lost or including less content. Again, adapting for teaching in the target language was very important. Teachers had to consider the simplest way of conveying the content using simple target language to ensure understanding (2); the lesson had to be more "scripted" (2); very thorough planning of language, resources and activities (2) and one teacher planned the same but needed help with the target language vocabulary.

Responses to how teachers adapted their methodology to support the CLIL approach fell into similar categories of language and types of activities. Considerations of language use were key: from planning to delivery teachers reduced vocabulary to the bare essentials and simplified language so that higher level vocabulary could be accessed (5) and provided scaffolding and vocabulary sheets and the use of peer explanations. Strategies to aid comprehension included greater reliance on pupil non-verbal responses e.g. hands up, along with the use of mime to put the message across (2); repetition (4), the use of many images to support vocabulary (3), verbal instructions supported by examples on the board (3), use of cognates (3) and checking for understanding frequently (2). The activities subject teachers reported to support learning through a foreign language involved pair work so that students were supported by a peer (4), more interactive activities to encourage pupils to express and develop opinions (3), a range of learning styles (2) variety (2) and more focus on speaking and writing. Language teachers who were teaching a subject felt the need to incorporate concepts of the other subject and focus more on the content (4).

Teachers were asked which elements of the lesson were conducted in the target language and which in English. The majority of teachers used the target language for the entire lesson (7) or most of it (5). These responses were qualified by, for example, "the entire lesson except the introduction" to explain how the session would work and to test them or "almost the entire lesson" as the language was fairly simple and supported with visuals. Others used the target language for the PowerPoint and all worksheets (2), for the introduction to the task (2), examples (2), starters and plenaries, the final leaflets and some instructions. English was used in order to aid pupil understanding; for example, for clarification purposes (3), to ensure understanding of the learning objectives and some instructions and explanations so that students knew exactly

LACLII Hunt, M. (2011). UK teachers' and learners' experiences of CLIL resulting from the EU-funded project ECLILT. Latin American Joumal of Content \& Language Integrated Leaming, 4(1), 27-39. doi: 10.5294/lacli1.2011.4.1.3 ISSN 2011-6721. 
what was going to happen, or for explanation by a pupil to check for understanding (3). One teacher mentioned the use of English just for the greeting and introduction to put the pupils at their ease; another used English mostly in conversation with less able pupils to assist and check for comprehension and one used English for practical activities "because the language of process is more difficult than that of content". In some cases English was used to explain more challenging outcomes or for some source materials which were too difficult to translate. In one case the teacher admitted to using English "when the target language became too difficult for me". Pupil language was a mixture of L1 and L2 (3), which did not detract from completion or communication of the task (2) to avoid language becoming a barrier (3). In some cases a vocabulary list was given in target language and English to enable pupils to say a greater amount of detail.

Teachers were asked to what extent pupils understood the subject content using the scale of 6 (fully) to 1 (not at all). The results demonstrated that pupils understood well the subject content with 3 teachers choosing 6 (fully), 12 choosing 5, only 2 choosing 4 and no scores lower than 4. Teachers reported a range of strategies used to help pupils understand and communicate. Many of these coincide with the responses above, for example, visual clues (8), mime (5), cognates (4), making the language as simple as possible and scaffolded (4), rephrasing or repetition (3), overt checking of understanding (2), modeling, demonstrating and examples (5), pupils as assistant (2) and important vocabulary translated into English. Teachers commented on making the objectives clear (2), planning concise amounts of learning and using support mechanisms such as providing key words, using PowerPoint and clear worksheets containing the target language students were asked to use (3). Activities were chosen to include interaction through pair work (4), and encouraging pupils' opinions and agreement verbally and nonverbally (2), in some cases providing a speaking frame to build up pupil participation (2). Resources to help understanding and communication included matching pictures to words (2), making sentences with cut out words and cards with phrases to help or word mats.

Teachers were asked about perceived differences in pupil behavior, attitude and motivation in CLIL lessons. All responses were positive indicating an improvement in these areas. Only one teacher commented that some pupils were suspicious of this new approach, although equally commented that others were very keen. Teachers' positive responses included that pupils were more focused and had a better attitude (6), pupil behavior was good (5), pupils were very motivated and engaged, and pupils stayed on task more (3). Improved behavior was the result of pupils having to listen and concentrate more to understand the task (3) and pupils were proud that they understood the lesson (2). Teachers reported that most pupils found it fun, that oral responses were increased as the content was interesting and that weaker pupils were more engaged because the language was only a means to what they were really learning.

Teachers were asked to comment on differences in pupil learning in CLIL lessons. Comments indicated that both able and less able pupils responded well to the CLIL approach. Able pupils 'really flew with this' and the level of vocabulary and syntax was superb. Furthermore weaker pupils were much more willing to try things and there was opportunity for the more able to help the less able. Generally pupils were more engaged due to the challenging nature of the lessons, greater levels of concentration were seen and the learning objectives were met. In one case the teacher said that the students seemed to grasp the idea better than previous students who had done it in English. Teachers again commented on a rise in the interaction level and a greater range of oral responses that were more spontaneous. The use of the foreign language increased motivation for some pupils who disliked the subject but liked languages and

LACLII Hunt, M. (2011). UK teachers' and learners' experiences of CLIL resulting from the EU-funded project ECLILT. Latin American Joumal of Content \& Language Integrated Leaming, 4(1), 27-39. doi: 10.5294/lacli1.2011.4.1.3 ISSN 2011-6721. 
therefore gained confidence because of their enjoyment of languages. However, some found the target language difficult and some made less progress in the subject than the teacher would have liked because they were restricted by their ability to express themselves in the target language. There were conflicting views about girls' and boys' reactions, with one teacher observing that the girls were more motivated than boys (the opposite to normal) and another observing that the boys reacted better and got more involved. Teachers commented on the increased cognitive function and the development of thinking skills for pupils as they were learning new concepts in the language rather than new names for already known words in their mother tongue. Perceived gains in pupil learning were reported as:

- Pupils met the subject learning objectives.

- Pupils were interested in learning for a real purpose so they committed themselves more to their learning and made greater progress.

- Pupils concentrated better.

- The two subjects consolidated each other.

- Weaker mathematicians found it more fun combined with French.

- Pupils were more confident.

- Pupils used some of the vocabulary, verbs and adjectives in normal MFL lessons.

- Better use of vocabulary and presentation skills.

- They were happy to have understood the lesson and met the objectives.

- Pupils were pleased and surprised they could answer questions in the target language. One of the final questions investigated teacher confidence in delivering CLIL lessons in the future. The teachers reported that following the training course they now felt confident to teach CLIL lessons in the future. Using the scale of 6 (fully) to 1 (not at all), 7 teachers felt fully confident, 6 very confident and 4 confident. This confidence arose from the motivation of doing something different to enrich the teaching experience and the challenge of a new experience that helped teachers break away from the routine (5). An awareness of the issues gave some teachers the confidence to "have a go" (3). It was clear that there were different issues for subject teachers and language teachers. The latter were concerned about getting the subject content right and the former were concerned about getting the language right and pitching the language at the right level. Cooperation between a subject teacher and language teacher helped to develop confidence in these areas. This collaboration with a colleague from a different department also helped both subjects to share and develop good practice (5). Several were happy with adapting the target language and creating resources and felt they could adapt them for future lessons (5).

Teachers were asked to report the impact of the CLIL training on their teaching and views of teaching. The teachers in the sample were experienced teachers, but nevertheless they recognized that this training was good professional development that gave them a chance to explore methodology and that refreshed their attention and maintained their interest. Many teachers expressed the benefits of reflection and re-evaluating their practice. For example some felt it had forced them to re-think their approach to planning and the advantages of simplicity and the need to think more thoroughly about the main objectives and more about how the pupils learn. Some appreciated the chance to see different approaches and ideas. For others it gave them the opportunity to re-evaluate their methodology and provide a greater focus on kinesthetic teaching and more varied and fun activities. Teachers realized that the higher the level of challenge, the more motivated the pupils become. This impacted on practice in both subject areas. Participants appreciated the opportunity for professional development and to reflect on their own teaching:

LACLII Hunt, M. (2011). UK teachers' and learners' experiences of CLIL resulting from the EU-funded project ECLILT. Latin American Joumal of Content \& Language Integrated Leaming, 4(1), 27-39. doi: 10.5294/lacli1.2011.4.1.3 ISSN 2011-6721. 
- "It really gets you to think about your own teaching again and refreshes the way in which you think about how you are going to introduce language and get students to use it."

- "I think CLIL really helps you to plan in non-CLIL lessons as well."

In informal interviews during the training course participants expressed their excitement about the new concept of teaching content through language:

- "It is a wonderful experience, we are all learning a lot. As a languages teacher it is breaking all the ideas I had about teaching a different subject. Teachers teaching content are worried about language, but language teachers need to think about how to deliver the content without concentrating all the time on the language."

\section{DISCUSSION}

The findings reported here represent the views of teachers following CLIL training through the ECLILT national course in England and their initial implementation of this approach in lessons in school. For the majority of the teachers involved this was a first attempt at this innovative practice. Coyle (2007, p. 546) claims that "the strength of CLIL focuses on integrating content and language learning in varied, dynamic and relevant learning environments built on 'bottomup' initiatives as well as 'top-down' policy". This project is clearly a "bottom-up" initiative where both subject and language teachers experimented with teaching content through language, building on their own classroom expertise and the CLIL training they received. Their positive experience could lead to further development of CLIL modules within their schools.

One of the main findings resulting from this research is the change in practice of the teachers involved to adopt a more interactive mode of delivery as a key strategy in teaching content through language. Coonan (2007, p. 633) reports similar findings:

Whereas as much as $90 \%$ of subject lessons in L1 would be frontal, in CLIL the teachers switch over to an interactive mode - including not only T-SS interaction but also SS-SS interaction. Indeed, through experience in CLIL the interactive mode is also seeping into the normal L1 lessons.

Ting et al. (2007, p. 3) also report a tendency towards "increased communicative interaction within CLIL classrooms" and go on to add that "although CLIL was developed primarily to enhance the second/foreign language education, it appears to also affect the teaching style/strategy of the teachers - the teachers tend to talk less, tend to encourage interaction with and between students"; there is "more student-initiated interaction" and "more sustained utterances".

Moreover, Ting et al. (2007, p. 5) pose the following question: "Is CLIL [passively] positive for language and content learning because it's done in another language or is there an [active] positive effect because CLIL classes/teachers are more motivated/enthusiastic than 'ordinary' content and language classes?" Both the subject and language teachers in this project were often anxious about their lack of expertise in either the language or the content. However, they were certainly enthusiastic and prepared to take risks, and they had the opportunity to learn from each other's practice. Their commitment to the success of their CLIL lessons generally meant that they spent more time on planning the structure of their lessons and they worked hard at creating resources and activities that would achieve effective learning outcomes and that would motivate and engage pupils, thus indicating a more active effect.

LACLII Hunt, M. (2011). UK teachers' and learners' experiences of CLIL resulting from the EU-funded project ECLILT. Latin American Joumal of Content \& Language Integrated Leaming, 4(1), 27-39. doi: 10.5294/lacli1.2011.4.1.3 ISSN 2011-6721. 


\section{CONCLUSION}

Whilst there are considerable benefits to the CLIL approach, nevertheless teachers of either content or language need specific training in CLIL pedagogy in order to ensure teacher expertise and learning gains. Ting et al. (2007, p. 5) recommend "the development of quality-enhanced teacher training and study materials"; the course that formed the object of the present study indeed helped provide this for groups of teachers throughout the ECLILT consortium of countries.

However, there remains some debate about CLIL in current and future curricula; Coyle (2006) stresses that, to gain its rightful place, CLIL has to demonstrate rigorous theoretical underpinning, substantiated by evidence in terms of learning outcomes and capacity building. In this small-scale research in the UK, attitudes towards CLIL have been positive, but training on a much larger scale and further research will be required to measure more closely the learning outcomes. Participants in the ECLILT training in other European countries were positive in their evaluations about the course, but it was only in the UK where participants were expected to implement their training in practice in schools and to report back. Further research of practice across the partner countries would help to build a broader basis and would enable the analysis of comparative data.

\section{REFERENCES}

Burns, A. (2005). Action research: an evolving paradigm? Language teaching, 38(2), 57-74.

CILT . (2009). CILT analysis of DCSF data: GCSE language entries trend analysis, 1994 to 2009. Retrieved from http://www.cilt.org.uk/home/research and statistics/statistics/secondary statistics/gcse exam entries.aspx

CLIL Compendium. (n.d.). Retrieved fromhttp://www.clilcompendium.com/clilcompendium.htm

CLIL National Statement and Guidelines. (July, 2009). Retrieved from http://www.languagescompany.com/news/81-featured-news/97-clil-national-statementand-guidelines-published-july-31.html

Commission of the European Communities. (2003). Promoting Language Learning and Linguistic Diversity: An Action Plan 2004-2006 (Brussells). Retrieved from http://eurlex.europa.eu/LexUriServ/site/en/com/2003/com2003 0449en01.pdf

Coonan, C. M. (2007). Insider Views of the CLIL Class Through Teacher Self-ObservationIntrospection, International Journal of Bilingual Education and Bilingualism, 10(5), 625646.

Coyle, D. (2006). CLIL in Catalonia: from theory to practice. APAC Monographs, 6. Gerona: APAC.

Coyle, D. (2007). Content and Language Integrated Learning: Towards a Connected Research Agenda for CLIL Pedagogies', International Journal of Bilingual Education and Bilingualism, 10: 5, 543-562.

Cummins, J. (1999). Immersion education for the millennium: What have we learned from 30 years of second language immersion? Retrieved from http://www.iteachilearn.com/cummins/immersion2000.html

DfES. (2002). Languages for All: Languages for Life. A strategy for England. Nottingham,: DfES publications.

DfES. (2007). The Languages Review. Retrieved from http://www.teachernet.gov.uk/ doc/11124/LanguageReview.pdf

LACLII Hunt, M. (2011). UK teachers' and learners' experiences of CLIL resulting from the EU-funded project ECLILT. Latin American Joumal of Content \& Language Integrated Leaming, 4(1), 27-39. doi: 10.5294/lacli1.2011.4.1.3 ISSN 2011-6721. 
Eurydice. (2006). CLIL at School in Europe. Retrieved from http://www.eurydice.org/portal/ page/portal/Eurydice/showPresentation?pubid=071EN

Genesee, F. (1994). Integrating Language and Content: Lessons from Immersion. Educational Practice Reports. No 11. National Center for Research on Cultural Diversity and Second Language Learning. Washington: Center for Applied Linguistics

Marsh, D. (2002). CLIL/EMILE - The European Dimension: Actions, Trends and Foresight Potential. European Commission: Public Services Contract DG EAC 3601: European Commission. Retrieved from http://ec.europa.eu/education/policies/lang/doc/ david marsh-report.pdf

Marsh, D. and Langé G. (eds.) (2002). Using Languages to Learn and Learning to Use Languages, TIE-CLIL: Milan. Retrieved from http://www.clilcompendium.com/1uk.pdf

Picciano, A. (2004). Educational research primer. London: Continuum.

The Nuffield Languages Inquiry. (2000). Languages: the next generation, London: The Nuffield Foundation.

Ting, Y.L.T., et al. (2007). A collective end-of-symposium reflection: The state of the art of CLIL and Future Prospects, AILA CLIL-Research Network Symposium, 20-22 September, 2007, retrieved from http:/www.ichm.org/clil/pdfs/summary symposium07.pdf

Zuber-Skerritt, O. (1996). Emancipatory action research for organizational change and management development. In O. Zuber-Skerritt (Ed) New directions in action research (pp. 83-105). London: Falmer.

\section{BIODATA}

Marilyn HunT is Associate Professor in Modern Foreign Languages (Teacher Education) at the University of Warwick where she works with trainee teachers and MFL staff in schools on a range of teaching and learning issues. Her research interests include primary languages, teaching and assessment in MFL and Content and Language Integrated Learning (CLIL). She has been involved in research projects with EU partners and recently led the UK team in an EU-funded project to investigate Content and Language Integrated Learning (CLIL). The innovative development of CLIL on the PGCE programme led to a 2009 European Award for languages and the TDA ITT School Partnerships prize. 